\title{
Molecular support for a basal grade of morphologically distinct, monotypic genera in the species-rich Vanguerieae alliance (Rubiaceae, Ixoroideae): Its systematic and conservation implications
}

\author{
Sylvain G. Razafimandimbison, ${ }^{1}$ Kent Kainulainen, ${ }^{1,2}$ Khoon M. Wong, ${ }^{3}$ Katy Beaver ${ }^{4}$ \& Birgitta Bremer ${ }^{1}$ \\ 1 Bergius Foundation, Royal Swedish Academy of Sciences and Botany Department, Stockholm University, 10691 Stockholm, Sweden \\ 2 Department of Botany, Stockholm University, 10691, Stockholm, Sweden \\ 3 Singapore Botanic Gardens, 1 Cluny Road, Singapore 259569 \\ 4 Plant Conservation Action Group, P.O. Box 392, Victoria, Mahé, Seychelles \\ Author for correspondence: Sylvain G. Razafimandimbison, sylvain.razafimandimbison@bergianska.se
}

\begin{abstract}
Many monotypic genera with unique apomorphic characters have been difficult to place in the morphology-based classifications of the coffee family (Rubiaceae). We rigorously assessed the subfamilial phylogenetic position and generic status of three enigmatic genera, the Seychellois Glionnetia, the Southeast Asian Jackiopsis, and the Chinese Trailliaedoxa within Rubiaceae, using sequence data of four plastid markers ( $n d h F, r b c L, r p s 16$, trnT-F). The present study provides molecular phylogenetic support for positions of these genera in the subfamily Ixoroideae, and reveals the presence of a basal grade of morphologically distinct, monotypic genera (Crossopteryx, Jackiopsis, Scyphiphora, Trailliaedoxa, and Glionnetia, respectively) in the species-rich Vanguerieae alliance. These five genera may represent sole representatives of their respective lineages and therefore may carry unique genetic information. Their conservation status was assessed, applying the criteria set in IUCN Red List Categories. We consider Glionnetia and Jackiopsis Endangered. Scyphiphora is recognized as Near Threatened despite its extensive range and Crossopteryx as Least Concern. Trailliaedoxa is poorly known (Data Deficient). Finally, the generic status of Glionnetia, Jackiopsis, and Trailliaedoxa and the monogeneric tribe Jackieae as defined by Ridsdale are supported.
\end{abstract}

Keywords conservation; Crossopteryx; Glionnetia; Jackiopsis; molecular systematics; Scyphiphora; Trailliaedoxa

\section{INTRODUCTION}

Rubiaceae (or the coffee family) are one of the most species-rich flowering plant families with a particularly high number of monotypic genera, which represent $34.5 \%$ of the genera (Davis \& al., 2009). The majority of these genera have been studied in previous molecular phylogenetic investigations of the family, and their generic status, systematic positions, and phylogenetic relationships have been assessed. Some monotypic genera have been synonymized, as they were shown to be part of much larger and well-defined genera (e.g., Aphaenandra Miq. now included in Mussaenda L., Alejandro \& al., 2005; Hymenocnemis Hook. f. now included in Gaertnera Lam., Malcomber \& Davis, 2005; Litosanthes Blume now included in Lasianthus Jack, Xiao \& Xhu, 2008; Rhopalobrachium Schltr. \& K. Krause now included in Cyclophyllum Hook. f., Mouly \& al., 2007; Schizostigma Arn. ex Meisn. now included in Sabicea Aubl., Khan \& al., 2008; Neoleroya Cavaco and Scyphochlamys Balf. f. now included in Pyrostria Comm. ex A. Juss., Razafimandimbison \& al., 2009). In contrast, the generic status of some monotypic genera (e.g., Strumpfia Jacq., Bremer \& al., 1995; Crossopteryx (Afzel. ex G. Don) Benth., Razafimandimbison \& Bremer, 2001; Burttdavya Hoyle, Razafimandimbison \& Bremer, 2002; Landiopsis Capuron ex Bosser, Alejandro \& al., 2005; Dunnia Tutcher, Rydin \& al., 2008) has been retained, because they are not nested within well-defined genera. Furthermore, they have at least one autapomorphic character allowing them to be easily identified (Backlund \& Bremer, 1998). The systematic placement of a few rubiaceous monotypic genera with particularly unique morphology remains either unknown or controversial due to the lack of sequenceable material. The present study focuses on the enigmatic genera Trailliaedoxa W.W. Sm. \& Forrest, Jackiopsis Ridsdale, and Glionnetia Tirvengadum (Fig. 1A-J).

Jackiopsis was originally described by Wallich (in Roxburgh, 1824) as Jackia Wall., but this latter name was already used for another genus Jackia Blume in the family Polygalaceae. As a result, Ridsdale (1979) proposed the name Jackiopsis for Wallich's intended genus. When establishing Jackia ornata Wall. (= Jackiopsis ornata (Wall.) Ridsdale) Wallich (in Roxburgh, 1824) wrote a very detailed description based on individual plants in flower and immature fruit that he had discovered "on several of the small islands in the immediate vicinity of Singapore". Jackiopsis is a large tree up to $35 \mathrm{~m}$ tall with spreading buttresses. The stipules are large, persistent, and connate into a sheath with 8 to 15 stiff, filiform lobes (Fig. 1D). Its inflorescences are axillary, large, pendulous, and paniculate with scorpioid lateral branches. The peduncles are typically flattened, articulated, and are composed of a primary peduncle unit, a secondary node, a secondary peduncle unit, a tertiary node, and a tertiary peduncle unit. Each secondary node bears a sheathed bract, and a pair of reduced leaves; each tertiary node bears a sheathed 
bract and is typically terminated by up to eight scorpioid inflorescences in umbel-like arrangement. Corolla lobe aestivation is valvate. Ovaries are bilocular with 2-5 ovules in each locule; the ovules are basally attached on ascending, stalked placentae. Fruits are dry, dehiscent, winged nutlets with persistent, reticulate, and accrescent calyx lobes (pterophylls) (Fig. 1E), commonly with only one seed per locule, as the remaining ovules are aborted (Wallich in Roxburgh, 1824; Ridsdale, 1979).

Korthals (1851) was the first to classify Jackiopsis (as Jackia) at tribal level. He placed the genus in his new tribe
Jackieae (as Jackiae) along with four other genera, Tricalysia A. Rich. and Diplospora DC. (now in tribe Coffeeae), Hypobathrum Blume (now in Octotropideae), and Scyphiphora Gaertn., all presently placed in the subfamily Ixoroideae. Hooker (1873) erroneously considered the corolla aestivation of Jackiopsis to be contorted and its fruits to be drupes with 5 to 7 pyrenes, and accordingly placed the genus in Retiniphylleae, now in subfamily Ixoroideae. Baillon (1878) postulated a close affinity between Jackiopsis, Cruckshanksia Hook. \& Arn., and Carphalea Juss. based on similarities in ovary structure, placentation, and fruits with reticulate pterophylls.

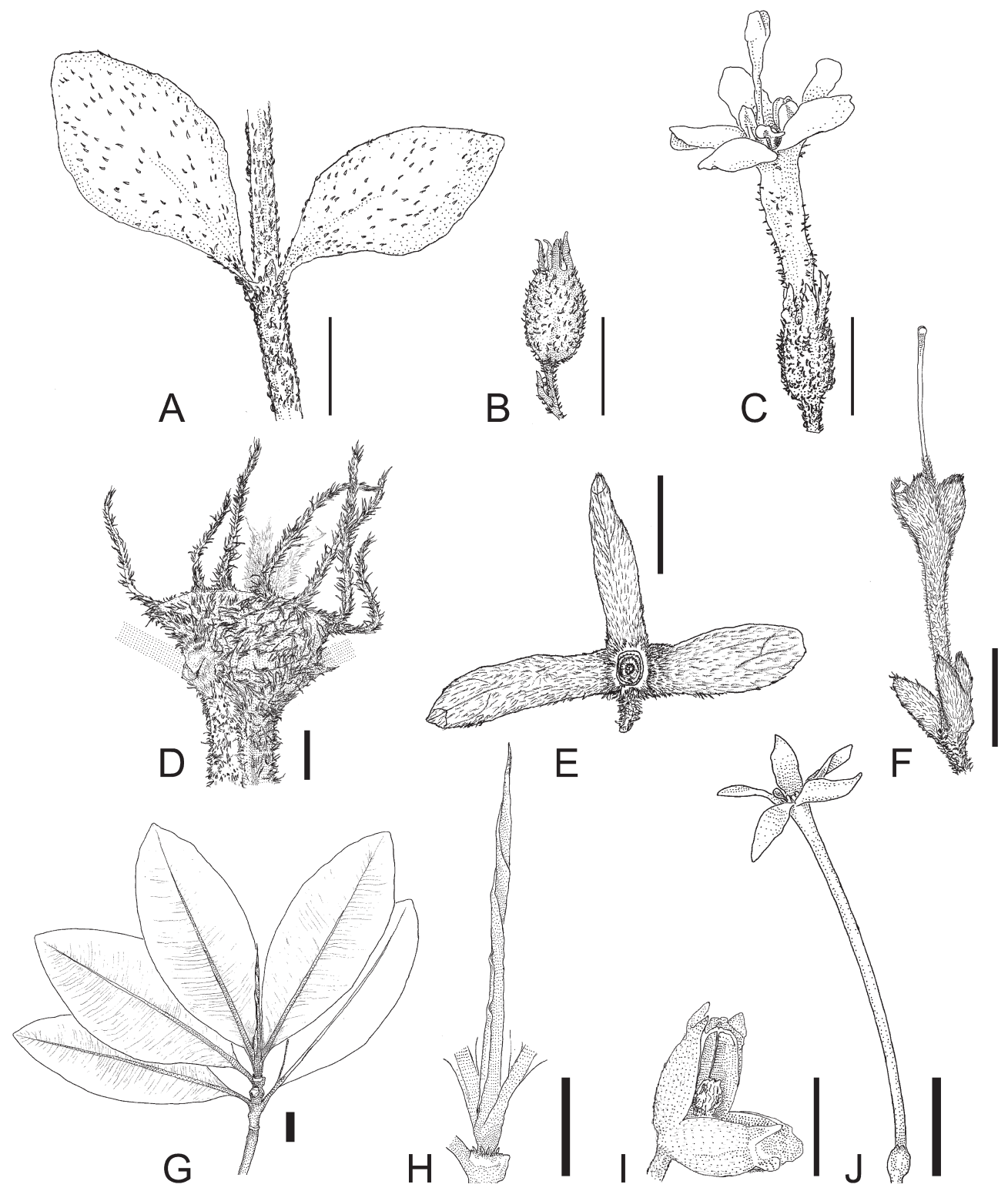

Fig. 1. Illustrations showing the morphological synapomorphies or characteristics of Trailliaedoxa, Jackiopsis, and Glionnetia. A-C, Trailliaedoxa gracilis: A, leafy twig; from Boufford \& al. 35041 (MO); B, immature fruit; from Yü 1348 (HUH); C, flower showing partly exserted anthers and a fully exserted stigma; from Forrest 12638 (S). D-F, Jackiopsis ornata: D, large, densely pubescent stipule with filiform lobes; from Kalat \& al. s.n. 1993-05-11 (L); E, dry, indehiscent fruit with three unequal lobes; from Van Balooy 6109 (MO); F, densely pubescent flower with three calyx lobes and a very long style; from Rahmat Si Toroes 3424 (S). G-J, Glionnetia sericea: G, habit showing a very long, convolute terminal vegetative bud (young stipule); from Beaver 03 (S); H, long, convolute stipule; from Beaver 03 (S); I, mature capsular fruit; from Beaver 17 (S); J, flower showing partly exserted anthers; from Beaver 17 (S). Scale bars: thin, 2 mm; medium, 5 mm; thick, 20 mm. 
The latter two genera are currently placed in the tribes Coussareeae and Knoxieae, respectively, in the subfamily Rubioideae. Schumann (1891) associated Jackiopsis with Rubioideae, viz. Oldenlandieae. More recently, Ridsdale (1979) narrowly recircumscribed Jackieae to include only the genus Jackiopsis and tentatively placed the tribe in the subfamily Cinchonoideae. Finally, the recent discovery of intra-ovarian trichomes in Jackiopsis (Puff \& Igersheim, 1994) and in some Malagasy species of Tricalysia (Ranarivelo-Randriamboavonjy \& al., 2007) could be taken as an indication of a close relationship between the two genera and would imply placing the former in the tribe Coffeeae of Ixoroideae.

Trailliaedoxa is an ericoid, erect subshrub (up to $60 \mathrm{~cm}$ tall), with a broom-like branching and small, tough leaves (Robbrecht, 1988). According to the protologue (Smith, 1917), the genus grows in the rocky habitats and thickets on dry mountain slopes of Sichuan, China, between 1450 and 3000 m elevation. Trailliaedoxa is very distinct from other Rubiaceae in its ericoid habit, pubescent styles, and schizocarpous fruits. The genus is presently unclassified at tribal level in Rubiaceae (Robbrecht, 1988). Smith (1917) thought that the floral structure of the genus is similar to that of Alberteae, now in Ixoroideae. On the other hand, its ericoid habit is also comparable to that of Spermadictyon Roxb. of the tribe Paederieae in the subfamily Rubioideae (Smith, 1917). Robbrecht (1988) tentatively placed Trailliaedoxa in the subfamily Antirheoideae, which was shown to be highly polyphyletic (e.g., Bremer \& al., 1995).

Finally, the genus Glionnetia was originally described by Tirvengadum (1984) to accommodate the Seychellois Randia sericea (Baker) Hemsl. (Hemsley, 1916: 18) that he excluded from the Neotropical genus Randia L. This monotypic genus is restricted to Mahé and Silhouette Islands of the Seychelles Archipelago; it is distinct by its large, long, intrapetiolar, and convolute stipules and can additionally be characterized by a combination of the following features: glabrous, coriaceous leaves clustered at the apex of the branches, corollas 6-7 cm long, left-contorted aestivation, and capsular fruits with loculicidal dehiscence (Fig. 1G-J). Tirvengadum (1984) originally classified Glionnetia in Rondeletieae of the subfamily Cinchonoideae. Robbrecht (1988), and more recently Rova \& al. (2009) and Manns \& Bremer (2010), tentatively followed this classification. None of the discussed hypotheses regarding systematic positions within Rubiaceae have been tested with molecular data.

We rigorously investigated the phylogenetic positions of Glionnetia, Jackiopsis, and Trailliaedoxa in Rubiaceae and assessed their generic status, using sequence data from four plastid markers ( $n d h F, r b c L, r p s 16$ intron, $t r n T-F)$. We found that these genera belong in the subfamily Ixoroideae, and that Crossopteryx, Jackiopsis, Scyphiphora, Trailliaedoxa, and Glionnetia, respectively, form a paraphyletic assemblage at the base of the species-rich Vanguerieae alliance. These results allowed us to hypothesize that these monotypic genera may represent sole representatives of their respective lineages. We discuss the systematic and conservation implications of these findings.

\section{MATERIALS AND METHODS}

Taxon sampling and laboratory work. - We extracted silica-gel leaf samples from three individuals of Jackiopsis ornata (from the Malay Peninsula), three individuals of Glionnetia sericea (from the Island of Mahé in the Seychelles Archipelago), and two individuals of Trailliaedoxa gracilis (from Yunnan, China), following the protocol outlined in Razafimandimbison \& al. (2008). The extracted DNA was amplified and sequenced for four chloroplast regions ( $n d h F, r b c L$, rps 16 intron, $\operatorname{trn} T-F)$, using the primers of Razafimandimbison \& al. (2008) and Rydin \& al. (2008).

Phylogenetic analyses. - Sequences were preliminary aligned using the Clustal W (default settings; Thompson \& al., 1994), as implemented in BioEdit v.7.0.9 (Hall, 1999), and subsequently edited manually. We initially performed maximum parsimony (MP) and Bayesian analyses of $120 \mathrm{rbcL}$ sequences of Rubiaceae (including all major lineages in the three subfamilies of Rubiaceae and the tribes Luculieae and Coptosapelteae, which do not belong in any of the three subfamilies) in order to pinpoint the subfamilial position(s) of the three genera within the family. Eight taxa from the other families of the order Gentianales (Apocynaceae, Gentianaceae, Gelsemiaceae, Loganiaceae) were utilized as outgroups following Bremer \& Eriksson (2009). Bayesian analysis of the $r b c L$ dataset was performed using the GTR $+\mathrm{G}+\mathrm{I}$ model. We refer to these MP and Bayesian $r b c L$ analyses hereafter as the "Family-Wide- $r b c L$ " analyses. The results of the Family-Wide-rbcL analyses allowed us to narrow down our sampling to include only the three targeted genera and their more closely related groups and select the outgroup taxa from within Rubiaceae (Cinchona L. and Cubanola Aiello [subfamily Cinchonoideae], Morinda L. [subfamily Rubioideae], and Luculia Sweet [Luculieae]). MP and Bayesian analyses of 71 taxa based on combined sequence data from the chloroplast markers $n d h F, r b c L$, rps 16 intron, and $\operatorname{trn} T-F$ were subsequently performed, of which 67 species represented all tribes currently recognized in Ixoroideae (with the exception of Henriquezieae) (see Appendix). We refer to these analyses hereafter as the "Ixoroideae-Four-Locus" analyses. We hoped that we could better resolve the position of these genera within subfamily Ixoroideae, by combining the two more rapidly evolving non-coding regions (rpsl6 intron, trnT-F) and the two coding regions $(n d h F, r b c L)$ in a single data matrix.

Separate and combined MP analyses of the $n d h F, r b c L$, rps16, and trnT-F datasets of the 71 taxa were conducted using the program PAUP* v.4.0B10 (Swofford, 2002). MP analyses consisted of a heuristic search with the TBR branch swapping algorithm, Multrees on, 1000 random sequence addition replicates and a maximum of 10 trees saved per replicate. Clade bootstrap support (BS) was estimated using the same settings and three random sequence additions per replicate.

The combined dataset was also analyzed using Bayesian inference (BI), using the program MrBayes v.3.1.2 (Huelsenbeck \& Ronquist, 2001; Ronquist \& Huelsenbeck, 2003). The combined data were partitioned in a protein-coding ( $r b c L$, $n d h F$ ) partition and a non-coding (rps16 intron, trnT-F) partition; these were unlinked and analyzed under the GTR $+\mathrm{G}+\mathrm{I}$ 
and GTR + G models, respectively, which were suggested as best-fit to the data under the corrected Akaike information criterion (AICc). The Bayesian $r b c L$ analysis of the 120 taxa and combined Bayesian analyses of the 71 taxa each comprised two runs of four chains, which were monitored for $15 \times 10^{6}$ generations, with every 1000th generation being sampled, and the temperature coefficient of the chain-heating scheme set to 0.15 . Stationarity and convergence of runs, as well as the correlation of split frequencies between the runs were checked using the program AWTY (Nylander \& al., 2008). Trees sampled before the posterior probability (PP) of splits stabilized, were excluded from consensus as a burn-in phase. The effective sample size (ESS) of parameters was checked using the program Tracer v.1.4.1 (Rambaut \& Drummond, 2007).

Finally, we assessed the conservation status of Crossopteryx, Glionnetia, Jackiopsis, Scyphiphora, and Trailliaedoxa, applying the criteria set in World Conservation Union (IUCN) Red List Categories (Version 3.1; IUCN, 2001).

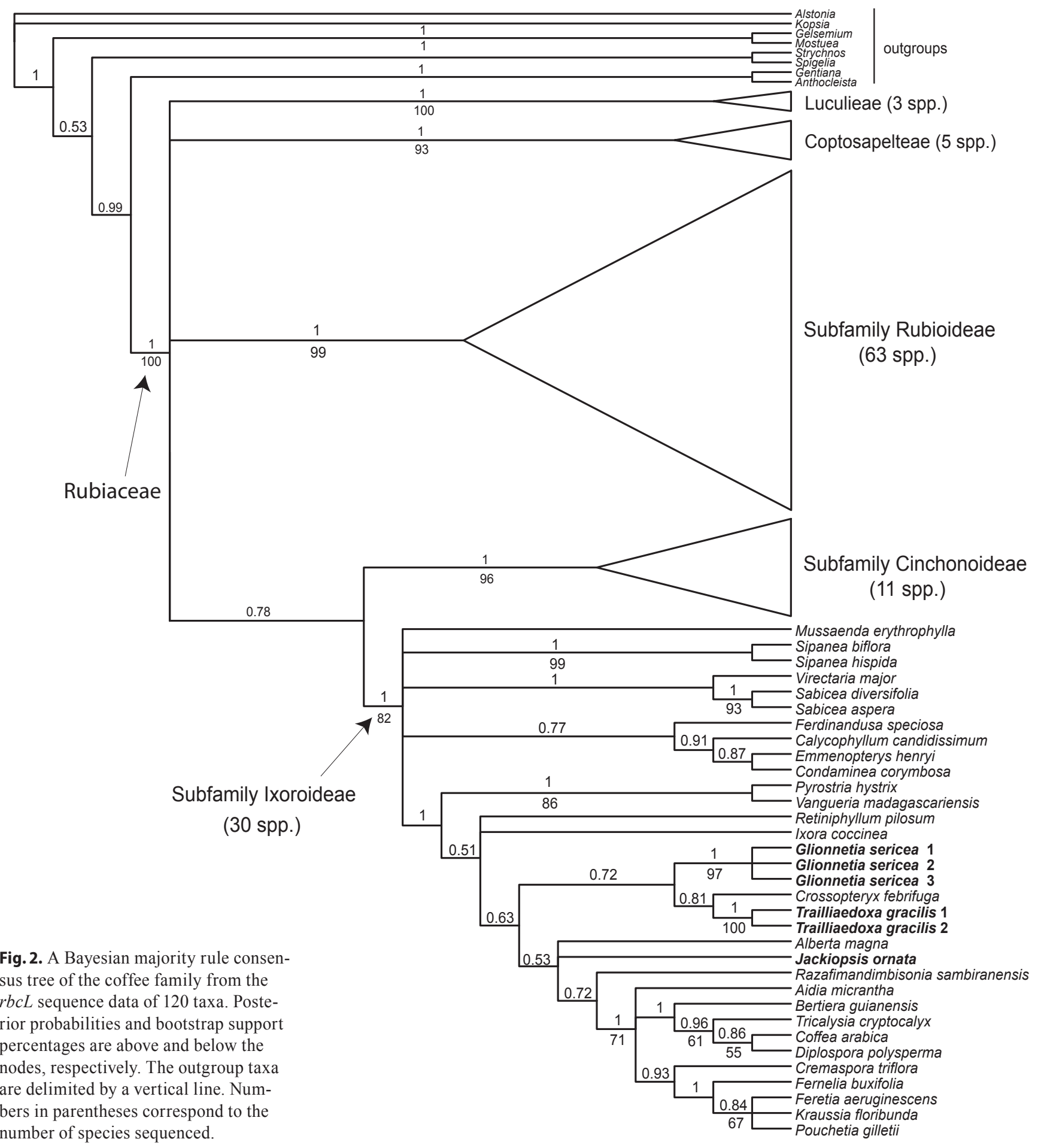




\section{RESULTS}

Separate analyses. - The Family-Wide- $r b c L$ analyses based on the $120 \mathrm{rbcL}$ sequence data placed all sampled Glionnetia, Jackiopsis, and Trailliaedoxa in the subfamily Ixoroideae ( $\mathrm{PP}=1.00 ; \mathrm{BS}=82 \%)$. The monophyly of Ixoroideae and its sister-group relationship with the subfamily Cinchonoideae is consistent with other published Rubiaceae studies (e.g., Robbrecht \& Manen, 2006; Bremer \& Eriksson, 2009; Rydin \& al., 2009). Glionnetia and Trailliaedoxa formed a poorly supported clade with Crossopteryx, while Jackiopsis was left unresolved in the poorly supported Coffeeae alliance $(\mathrm{PP}=0.53)$ (Fig. 2). A summary of the tree data and statistics from the analyses is given in Table 1. In the separate Ixoroideae analyses of the 71-taxa datasets, the incongruent nodes between the separate cpDNA markers generally received weak support (trees not shown), with the exception of a node inferred from the trnT$F$ data: a clade consisting of Condamineeae, Sipaneeae and Posoquerieae, as sister to the rest of the Ixoroideae (BS $=81 \%$; $\mathrm{PP}=0.96$ ) excluding Mussaendeae and Sabiceeae (inferred as sister groups in a basal clade).

Combined analyses. - The phylogenetic hypotheses inferred from the MP and BI analyses of the Ixoroideae-FourLocus datasets were in general agreement, with the exception of the position of Tocoyena pittieri, resolved as sister to Gardenia hansemanii in the former ( $\mathrm{BS}=53 \%$ ), and as sister to Aulacocalyx jasminiflora in the latter $(\mathrm{PP}=0.89)$.

The uncorrected potential scale reduction factor (PSRF; Gelman \& Rubin, 1992) of the summarized parameters approached 1.0, and the split frequencies between the runs were highly correlated, indicating that the runs had converged. The ESS of all model parameters were $>200$, as recommended by Drummond \& al. (2007) for adequate representation of the posterior probability. The $50 \%$ majority-rule consensus tree inferred from the BI analysis of the Ixoroideae-Four-Locus data is shown in Fig. 3.

The sampled specimens of Glionnetia, Jackiopsis, and Trailliaedoxa formed, respectively, highly supported clades (PP $=1.00 ; \mathrm{BS}=100)$ and were all nested in the highly supported Vanguerieae alliance (Fig. 3). Within this alliance the monotypic African genus Crossopteryx was the first to branch off, followed by Jackiopsis, Scyphiphora, Trailliaedoxa, and Glionnetia, respectively. Glionnetia was in turn resolved with poor support as sister to a poorly supported large clade containing Vanguerieae, Greeneeae, Aleisanthieae, and Ixoreae. Within this latter clade Aleisanthieae and Ixoreae formed a sister group, which in turn was sister to Greeneeae. The (Greeneeae(AleisanthieaeIxoreae)) clade was sister to Vanguerieae.

\section{- DISCUSSION}

Subfamilial position of Glionnetia, Jackiopsis and Trailliaedoxa within Rubiaceae: New circumscription of the Vanguerieae alliance. - The present study is the first molecular phylogenetic investigation of the Seychellois genus Glionnetia, the Southeast Asian Jackiopsis, and the Chinese genus Trailliaedoxa. The results of the Family-Wide-rbcL analysis (Fig. 2) support the placement of these monotypic genera in the subfamily Ixoroideae sensu Bremer \& Eriksson (2009). The phylogenetic hypothesis from the Ixoroideae-Four-Locus analyses (Fig. 3) reveals that the Vanguerieae alliance of the subfamily Ixoroideae contains the following major lineages: the African Crossopteryx (Crossopterygeae), Jackiopsis (Jackieae sensu Ridsdale), the mangrove genus Scyphiphora, Trailliaedoxa, Glionnetia, all currently unplaced at tribal level, and the tribes Vanguerieae, Aleisanthieae, Greeneeae, and Ixoreae. This alliance is species-rich and morphologically diverse, and contains over 1100 species of shrubs and small trees; it does not seem to have any obvious synapomorphic character, however the majority of its members (i.e., those of the species-rich tribes Ixoreae and Vanguerieae) have flowers showing secondary pollen presentation, drupaceous fruits, and one-seeded carpels. Ixoreae is pantropical, while the remaining lineages are paleotropical. An overview of the morphological and ecological characteristics of these major lineages of the Vanguerieae alliance is shown in Table 2.

Tribal positions and generic status of Glionnetia, Jackiopsis and Trailliaedoxa. - The morphologically unique genera Glionnetia, Jackiopsis, and Trailliaedoxa represent a paraphyletic basal assemblage within the Vanguerieae alliance (Fig. 3). Assessment and recognition of these monotypic genera and their tribal positions are discussed on the basis of a combination of the following criteria (Backlund \& Bremer, 1998; Razafimandimbison \& Bremer, 2002): (1) if they are not nested within other well-defined genera; and (2) if they have at least one

Table 1. Characteristics of the markers/datasets used, including statistics of alignments, analyses, as well as parameter estimates and evolutionary models suggested by MrModeltest 2.2 (Nylander, 2004).

\begin{tabular}{llllllll}
\hline & $n d h F$ & $r b c L$ & $r p s 16$ & trnT-F & Combined & Coding & Noncoding \\
\hline Number of taxa & 40 & 53 & 65 & 66 & 66 & 56 & 66 \\
Included characters & 2159 & 1403 & 1073 & 2441 & 7076 & 3562 & 3514 \\
Variable characters & 677 & 291 & 382 & 886 & 2236 & 968 & 1268 \\
Parsimony-informative characters & 353 & 158 & 227 & 465 & 1203 & 511 & 692 \\
\% informative characters & 16.35 & 11.26 & 21.16 & 19.05 & 17.00 & 14.35 & 19.69 \\
Consistency index (CI) & 0.70 & 0.54 & 0.68 & 0.75 & 0.68 & 0.64 & 0.72 \\
Retention index (RI) & 0.73 & 0.64 & 0.82 & 0.82 & 0.77 & 0.69 & 0.82 \\
\hline
\end{tabular}




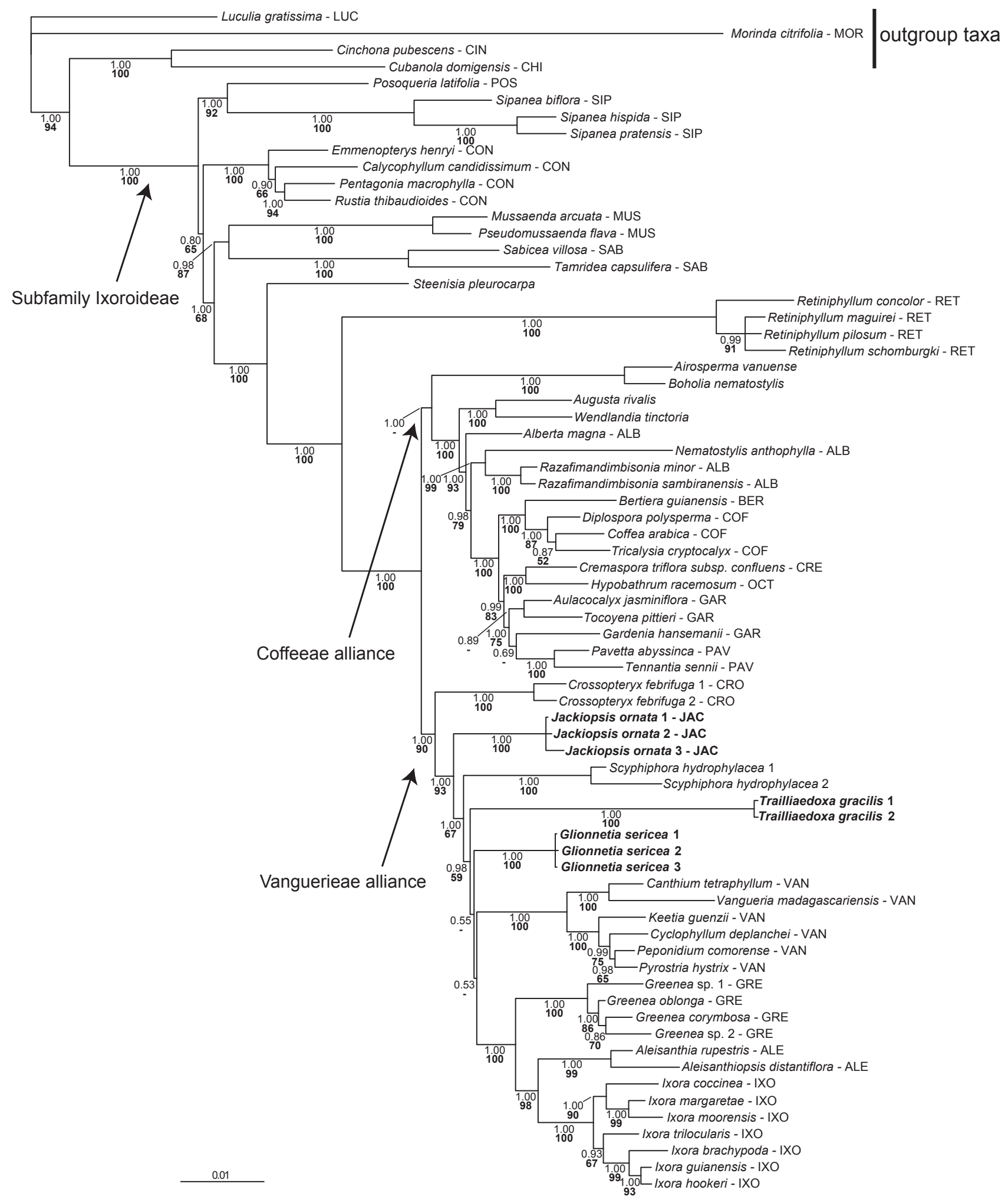

Fig. 3. Bayesian majority-rule consensus tree of the subfamily Ixoroideae from the combined $n d h F / r b c L / r p s 16 / t r n L-F$ data. Below branches are posterior probabilities and bootstrap support percentages (bold). Bootstrap support $<50 \%$ is indicated by a dash. The outgroup taxa are delimited by a vertical line. ALB, Alberteae; ALE, Aleisanthieae; CHI, Chiococceae; CIN, Cinchoneae; COF, Coffeeae; CON, Condamineeae; CRE, Cremasporeae; CRO, Crossopterygeae; GAR, Gardenieae; GRE, Greeneeae; IXO, Ixoreae; JAC, Jackieae; LUC, Luculieae; MUS, Mussaendeae; OCT, Octotropideae; PAV, Pavetteae; POS, Posoquerieae; RET, Retiniphylleae; SAB, Sabiceeae; SIP, Sipaneeae; VAN, Vanguerieae. The positions of the subfamily Ixoroideae and the Coffeeae and Vanguerieae alliances are indicated. The sampled specimens of Glionnetia, Jackiopsis, and Trailliaedoxa are in boldface. 
autapomorphic character or a combination of plesiomorphic characters, allowing them to be recognized easily.

Glionnetia, Jackiopsis or Trailliaedoxa are not nested within the five currently recognized tribes (Aleisanthieae, Crossopterygeae, Greeneeae, Ixoreae, Vanguerieae) of the Vanguerieae alliance. Like the monogeneric tribe Crossopterygeae, each of these three genera can also be placed in their own tribes, as they have distinct morphological features that warrant tribal recognition.

The large, persistent, and sheathed stipules with $8-15$ filiform lobes and the large (Fig. 1D), paniculate inflorescences with scorpioid lateral branches are unique for Jackiopsis in the Vanguerieae alliance and may represent potential apomorphies for the genus. A combination of valvate aestivation and dry, indehiscent fruits with pterophylls (Fig. 1E) can additionally be used to characterize Jackiopsis. Within the Vanguerieae alliance the members of Vanguerieae also have valvate aestivation but their fruits are drupes (Table 2). Dry fruits with pterophylls are also found in some other rubiaceous genera (e.g., Steenisia Bahk. f., Bremer, 1984; Cosmocalyx Standl., Delprete, 1998; Alberta E. Mey, Kainulainen \& al., 2009). Furthermore, the Ixoroideae-Four-Locus analyses (Fig. 3) support the monogeneric tribe Jackieae as circumscribed by Ridsdale (1979). Consequently, an older view of Jackieae (Korthals, 1851), as containing Diplospora, Hypobathrum, Jackiopsis, Scyphiphora, and
Tricalysia, is highly polyphyletic. The phylogenetic positions of Diplospora and Tricalysia in Coffeeae and Hypobathrum in Octotropideae have been shown by many independent molecular phylogenetic studies (e.g., Andreasen \& Bremer, 2000; Robbrecht \& Manen, 2006). The fourth genus Scyphiphora has been shown to be closely related to Aleisanthieae, Greeneeae, Ixoreae, and Vanguerieae of the Vanguerieae alliance (e.g., Robbrecht \& Manen, 2006; Bremer \& Eriksson, 2009; Cortés-B. \& al., 2009; Mouly \& al., 2009). A close relationship of Jackiopsis with the former Hedyotideae (now Knoxieae in subfamily Rubioideae) as put forward by Baillon (1878) and Schumann (1891) is not supported by this study (Fig. 2).

The Ixoroideae-Four-Locus analyses (Fig. 3) strongly support the position of Glionnetia in the Vanguerieae alliance, although its relationship to other taxa within the alliance is poorly resolved. This finding is inconsistent with Tirvengadum (1984), who tentatively placed the genus in Rondeletieae of the subfamily Cinchonoideae. Within Rondeletieae, Tirvengadum (1984) postulated a close relationship to the genus Lindenia Benth. (now Augusta Pohl), a genus that has recently been demonstrated to have a close affinity with the genus Wendlandia Bartl. ex DC. (Rova \& al., 2002) of the Coffeeae alliance of Ixoroideae (Fig. 3). The long, intrapetiolar, and convolute stipules are unique for Glionnetia within the Vanguerieae alliance, and may represent a potential apomorphy for the

Table 2. Morphological characteristics and other important information of the major lineages of the Vanguerieae alliance.

\begin{tabular}{|c|c|c|c|c|c|c|c|c|c|}
\hline Character & $\begin{array}{l}\text { Cross- } \\
\text { opterygeae }\end{array}$ & Jackieae & $\begin{array}{l}\text { Scyphi- } \\
\text { phora }\end{array}$ & $\begin{array}{l}\text { Traillaiae- } \\
\text { doxa }\end{array}$ & Glionnetia & $\begin{array}{l}\text { Vangu- } \\
\text { erieae }\end{array}$ & $\begin{array}{l}\text { Aleisan- } \\
\text { thieae }\end{array}$ & Greeneeae & Ixoreae \\
\hline Distribution & $\begin{array}{l}\text { Tropical } \\
\text { Africa }\end{array}$ & SE Asia & $\begin{array}{l}\text { SE Asia } \\
\text { and Mada- } \\
\text { gascar }\end{array}$ & $\begin{array}{l}\text { Yunnan, } \\
\text { Sichuan, } \\
\text { China }\end{array}$ & Seychelles & $\begin{array}{l}\text { Paleo- } \\
\text { tropics }\end{array}$ & SE Asia & SE Asia & Pantropical \\
\hline Habit & $\begin{array}{l}\text { Shrubs } \\
\text { to small } \\
\text { trees }\end{array}$ & $\begin{array}{l}\text { Tall to } \\
\text { emergent } \\
\text { trees }\end{array}$ & Shrubs & $\begin{array}{l}\text { Subshrubs } \\
\text { (up to } \\
60 \mathrm{~cm} \text { tall) }\end{array}$ & $\begin{array}{l}\text { Small } \\
\text { trees }\end{array}$ & $\begin{array}{l}\text { Small trees, } \\
\text { shrubs or } \\
\text { herbs }\end{array}$ & Shrubs & $\begin{array}{l}\text { Shrubs } \\
\text { or small } \\
\text { trees }\end{array}$ & Shrubs \\
\hline Inflorescence position & Terminal & $\begin{array}{l}\text { Axillary } \\
\text { (rarely } \\
\text { axillary/ } \\
\text { terminal) }\end{array}$ & Axillary & $\begin{array}{l}\text { Terminal/ } \\
\text { axillary }\end{array}$ & Terminal & Axillary & $\begin{array}{l}\text { Terminal/ } \\
\text { axillary }\end{array}$ & Terminal & $\begin{array}{l}\text { Terminal/ } \\
\text { cauli- } \\
\text { florous }\end{array}$ \\
\hline Inflorescence type & Paniculate & $\begin{array}{l}\text { Panicu- } \\
\text { late with } \\
\text { scorpioid } \\
\text { lateral } \\
\text { branches }\end{array}$ & Cymose & $\begin{array}{l}\text { Cymose to } \\
\text { umbelli- } \\
\text { form or } \\
\text { fasciculate }\end{array}$ & Paniculate & Cymose & Scorpioid & Scorpioid & $\begin{array}{l}\text { Cymose/ } \\
\text { paniculate }\end{array}$ \\
\hline Corolla aestivation & $\begin{array}{l}\text { Left- } \\
\text { contorted }\end{array}$ & Valvate & $\begin{array}{l}\text { Left- } \\
\text { contorted }\end{array}$ & $\begin{array}{l}\text { Left- } \\
\text { contorted }\end{array}$ & $\begin{array}{l}\text { Left- } \\
\text { contorted }\end{array}$ & Valvate & $\begin{array}{l}\text { Left- } \\
\text { contorted }\end{array}$ & $\begin{array}{l}\text { Left- } \\
\text { contorted }\end{array}$ & $\begin{array}{l}\text { Left- } \\
\text { contorted }\end{array}$ \\
\hline Ovules per carpel & Few & $2-5$ & 2 & 1 & Many & 1 & Many & Many & 1 \\
\hline Fruit type & Capsular & $\begin{array}{l}\text { Samara- } \\
\text { like }\end{array}$ & $\begin{array}{l}\text { Non-fleshy, } \\
\text { drupaceous }\end{array}$ & $\begin{array}{l}\text { Schizo- } \\
\text { carpous }\end{array}$ & Capsular & $\begin{array}{l}\text { Drupa- } \\
\text { ceous }\end{array}$ & Capsular & Capsular & $\begin{array}{l}\text { Drupa- } \\
\text { ceous }\end{array}$ \\
\hline Dispersal mode & $\begin{array}{l}\text { Anemo- } \\
\text { chorous }\end{array}$ & $\begin{array}{l}\text { Anemo- } \\
\text { chorous }\end{array}$ & $\begin{array}{l}\text { Sea } \\
\text { currents }\end{array}$ & $\begin{array}{l}\text { Anemo- } \\
\text { chorous }\end{array}$ & $\begin{array}{l}\text { Anemo- } \\
\text { chorous }\end{array}$ & $\begin{array}{l}\text { Zoo- } \\
\text { chorous }\end{array}$ & $\begin{array}{l}\text { Anemo- } \\
\text { chorous }\end{array}$ & $\begin{array}{l}\text { Anemo- } \\
\text { chorous }\end{array}$ & $\begin{array}{l}\text { Zoo- } \\
\text { chorous }\end{array}$ \\
\hline Pollen type & Colporate & Colporate & Colporate & Colporate & Colporate & Porate & $\begin{array}{l}\text { Pororate/ } \\
\text { colporate }\end{array}$ & Colporate & Colporate \\
\hline
\end{tabular}


genus. The genus can be confused with some members of Ixoreae because of its arborescent growth habit, terminal and paniculate inflorescences, and large, 5-merous flowers with left-contorted aestivation. However, Glionnetia bears capsular fruits with many-seeded carpels, while the members of Ixoreae have drupaceous fruits with one-seeded carpels (Table 2). Futhermore, Glionnetia and Crossopteryx have arborescent growth habit, terminal, paniculate inflorescences, left-contorted aestivation, and capsular fruits. However, these genera have very distinct seeds: the former with very small (2-3 mm long), unwinged seeds (Tirvengadum, 1984) and the latter with large, flattened seeds with deeply fimbriate wings (Stoffelen \& al., 1996). Additionally, Crossopteryx is restricted to tropical Africa, while Glionnetia is endemic to the Seychelles. For now, we leave Glionnetia unclassified at tribal level pending further analyses.

Trailliaedoxa was considered to be a genus with uncertain phylogenetic position within the family Rubiaceae (Smith, 1917; Robbrecht, 1988). Smith (1917) thought that the floral structure of the genus is similar to that of Alberteae sensu Hooker (1873), which is characterized by contorted aestivation and solitary pendulous ovules. On the other hand, its ericoid habit has been compared to that of Spermadictyon of the tribe Paederieae in the subfamily Rubioideae (Smith, 1917). Our Ixoroideae-FourLocus analyses (Fig. 3) place Trailliaedoxa in the Vanguerieae alliance. This position is consistent with the frequent occurrence of contorted aestivation in Ixoroideae, particularly in the Coffeeae and Vanguerieae alliances. Trailliaedoxa is very distinct from other genera in the alliance because of its ericoid habit, densely pubescent styles, and schizocarpous fruits.

Based on the results of the analyses presented (see also Table 2), we maintain the generic status of Glionnetia, Jackiopsis, and Trailliaedoxa and the tribal status of Jackieae as delimited by Ridsdale (1979). We suggest that Trailliaedoxa and Scyphiphora be recognized at tribal level. However, the formal recognition of the two respective new tribes will be published in another paper focusing on the tribal assessment and relationships in the subfamily Ixoroideae (Kainulainen \& al., subm.).

A basal grade of monotypic genera in the species-rich Vanguerieae alliance and its conservation implications. The Ixoroideae-Four-Locus analyses (Fig. 3) reveal a basal grade of morphologically distinct, monotypic genera (Crossopteryx, Jackiopsis, Scyphiphora, Trailliaedoxa, and Glionnetia, respectively) in the otherwise species-rich Vanguerieae alliance. In other words, these monotypic genera form a paraphyletic assemblage at the base of the alliance. These results here presented are interesting from both phylogenetic and conservation standpoints, as these genera may be sole representatives of their respective lineages and therefore may carry unique genetic information. Their extinction would mean loss of their entire lineages (see also Rydin \& al., 2008; Rana \& Ranade, 2009). These monotypic genera could be potential candidates for conservation priorities due to their genetic isolation, however this latter should not automatically be reason for conservation concern. Below we present conservation assessments of these five genera, applying the criteria set in World Conservation Union (IUCN) Red List Categories (IUCN, 2001).
- Crossopteryx febrifuga is a shrub or small tree species restricted to the savanna woodlands of tropical Africa. The species is common and widespread throughout tropical Africa and is fire resistant due to its thick bark (Gignoux \& al., 1997); it is widely used as a medicinal plant across much of tropical Africa but is not considered endangered. At present, it may represent less of a conservation priority, and therefore, we consider it to be Least Concern (IUCN, 2001).

- Jackiopsis ornata is restricted to Southeast Asia and distributed in the Malay Peninsula, Sumatra, Borneo, and the Riau Archipelago (Ridsdale, 1979). According to Sosef \& al. (1998), the species is "reported to be locally frequent but never common in lowland swamp forests and riverine habitats"; the wood of J. ornata is "rarely and only locally used". It was considered by UNEP-WCMC (2008) to be a timber tree species, which is not in the international trade or of conservation concern. However, the occurrence of this species appears patchy and is not registered in most peat swamp forest inventories (e.g., Kishokumar, 2008). In Southeast Asia, there has been much large-scale conversion of peatlands into commercial agriculture, such as for oil palms (Aiken \& Leigh, 1992; Jomo \& al., 2004; Kathirithamby-Wells, 2005). In addition, the frequent fires degrading peat swamp forests on Borneo (Sosef \& al., 1998) and Sumatra (Anderson \& Bowen, 2000) already had a tremendous impact on the natural habitats of $J$. ornata. Based on the information presented above, we consider $J$. ornata Endangered (IUCN, 2001). Therefore, an ex situ conservation plan for this unique taxon is strongly encouraged. The gregarious flowering and stately habit of mature $J$. ornata trees, with spectacular displays of dense, brightly colored inflorescences, should provide an added incentive for future conservation and planting.

- Scyphiphora hydrophylacea is a mangrove plant. It is distributed from East India throughout the Indo-Malesian region to the West Pacific and northern Australia, Sri Lanka, and Madagascar (Puff \& al., 2007). The wide coastal distribution range can be attributed to the trans-oceanic dispersal of its buoyant fruits. Mangrove stands are highly threatened ecosystems and exploited for fuelwood and timber, local constructions, development of salt beds, and conversion to aquaculture ponds (e.g., Tomlinson, 1986; Primavera, 2000). For example, mangrove areas in the Philippines decreased from 428,382 ha (Villaluz, 1953) to 200,500 ha (DENR, 1996) between 1951 and 1995. About $50 \%$ of the Philippine mangroves that disappeared from 1950 to 1988 had been converted into culture ponds, making aquaculture the main cause of the mangrove loss in the Philippines (Primavera, 2000). Scyphiphora hydrophylacea is reported to be rare and highly threatened in Sri Lanka and Peninsular India, where seedlings and young plants are scarce. This situation has been attributed to a very low percentage of fertile fruits in $S$. hydrophylacea and its inability to produce healthy seedlings, which is possibly due to inbreeding depression in small, isolated populations (Hettiarachchi \& Jayaratne, 2006). According to Puff \& al. (2007), S. hydrophylacea is usually not present in large populations in Thailand. Within its center of distribution in Southeast Asia, there is much alteration and destruction of its habitat. Largely ignored by 
forestry inventories or conservation projects, the occurrence of $S$. hydrophylacea is rare or patchy along the more frequently inundated mangrove fringes and adjacent shores. Occurrence is largely insignificant to absent within the main formation that is dominated by taller stands of Rhizophoraceae and other tree species. Moreover, conversion to other land use or subsequent degradation due to adjacent coastal development can drastically reduce mangrove extents (Chan \& al., 1993; Sasekumar $\&$ Then, 2005). Based on the evidence for concern presented above, we consider S. hydrophylacea Near Threatened (IUCN, 2001) despite its extensive range.

- Trailliaedoxa gracilis appears to have a narrow distribution range. Endemic to southern China, it grows in rocky habitats and thickets on the mountain slopes of Sichuan and Yunnan at an altitude of 1540 to $3000 \mathrm{~m}$. The conservation status of the genus is currently unknown, as it is only known from a few specimens. Trailliaedoxa gracilis may be a potential candidate for a high conservation priority, however it is poorly known (= Data Deficient; IUCN, 2001).

- Finally, Glionnetia sericea is confined to a very restricted area less than 1000 ha on Mahé and Silhouette Islands in the Seychelles Archipelago. It is one of two genera of Rubiaceae endemic to the Seychelles and has been considered Vulnerable D2 (IUCN, 2010). However, a recent assessment concluded that the species is Endangered Blab(iii) $+2 \mathrm{ab}$ ((iii) (Huber, pers. comm.). Glionnetia sericea thrives mainly on high ridges in the mountains (Tirvengadum, 1984); it does not seem to grow well at lower altitudes (K. Beaver, pers. comm.). Conservation in situ is strongly encouraged.

\section{ACKNOWLEDGEMENTS}

The authors thank Anbar Khodanbadeh for help with sequencing; the three anonymous reviewers and Elmar Robbrecht for their constructive criticisms on an earlier version of the paper; the Seychellois authority for approving our research proposal to collect Glionnetia for this study; and the following herbaria for allowing access to their collections: BR, K, L, NY, P, S, SING, TAN, TEF, and UPS. This work is supported by the Swedish Research Council and the Knut and Alice Wallenberg Foundation to BB.

\section{- LITERATURE CITED}

Aiken, S.R. \& Leigh, C.L. 1992. Vanishing rain forests: The ecological transition in Malaysia. Oxford: Clarendon Press.

Alejandro, G.D., Razafimandimbison, S.G. \& Liede-Schumann, S. 2005. Polyphyly of Mussaenda inferred from ITS and trnT-F data and its implication for generic limits in Mussaendeae (Rubiaceae). Amer. J. Bot. 92: 544-557.

Anderson, I.P. \& Bowen, M.R. 2000. Fire zones and the threat to the wetlands of Sumatra, Indonesia. Palembang: Forest Fire Prevention and Control Project.

Andersson, L. \& Antonelli, A. 2005. Phylogeny of the tribe Cinchoneae (Rubiaceae), its position in Cinchonoideae, and description of a new genus, Ciliosemina. Taxon 54: 17-28.

Andersson, L. \& Rova, J.H.E. 1999. The rps16 intron and the phylogeny of the Rubioideae (Rubiaceae). Pl. Syst. Evol. 214: 161-186.
Andreasen, K., Baldwin, B.G. \& Bremer, B. 1999. Phylogenetic utility of the nuclear rDNA ITS region in subfamily Ixoroideae (Rubiaceae): Comparisons with cpDNA $r b c L$ sequence data. Pl. Syst. Evol. 217: 119-135.

Andreasen, K. \& Bremer, B. 1996. Phylogeny of the subfamily Ixoroideae (Rubiaceae). Opera Bot. Belg. 7: 119-138.

Andreasen, K. \& Bremer, B. 2000. Combined phylogenetic analysis in the Rubiaceae-Ixoroideae: Morphology, nuclear and chloroplast DNA data. Amer. J. Bot. 87: 1731-1748.

Backlund, A. \& Bremer, K. 1998. To be or not to be: Principles of classification and monotypic plant families. Taxon 47: 391-400.

Backlund, M., Oxelman, B. \& Bremer, B. 2000. Phylogenetic relationships within the Gentianales based on $n d h F$ and $r b c L$ sequences, with particular reference to the Loganiaceae. Amer. J. Bot. 87: $1029-1043$.

Baillon, H. 1878. Sur l'organisation et les affinities du Jackia. Bull. Mens. Soc. Linn. Paris 1: 185-188.

Bremer, B. 1984. The genus Steenisia (Rubiaceae) and its taxonomic position. Nord. J. Bot. 4: 333-345.

Bremer, B., Andreasen, K. \& Olsson, D. 1995. Subfamilial and tribal relationships in the Rubiaceae based on $r b c L$ sequence data. Ann. Missouri Bot. Gard. 82: 383-397.

Bremer, B., Bremer, K., Heidari, N., Erixon, P., Olmstead, R.G., Anderberg, A., Källersjö, M. \& Barkhordarian, E. 2002. Phylogenetics of asterids based on 3 coding and 3 non-coding chloroplast DNA markers and the utility of non-coding DNA at higher taxonomic levels. Molec. Phylog. Evol. 24: 274-301.

Bremer, B. \& Eriksson, T. 2009. Time tree of Rubiaceae: Phylogeny and dating of the family, subfamilies, and tribes. Int. J. Pl. Sci. 170: 766-793.

Bremer, B., Jansen, R.K., Oxelman, B., Backlund, M., Lantz, H. \& Kim, K.J. 1999. More characters or more taxa for a robust phylogeny - case study from the coffee family (Rubiaceae). Syst. Biol. 48: 413-435.

Bremer, B. \& Thulin, M. 1998. Collapse of Isertieae, re-establishment of Mussaendeae, and a new genus of Sabiceeae (Rubiaceae); phylogenetic relationships based on $r b c L$ data. Pl. Syst. Evol. 211: $71-92$.

Chan, H.T., Ong, J.E., Gong, W.K. \& Sasekumar, A. 1993. The socioeconomic, ecological and environmental values of mangrove ecosystems in Malaysia and their present state of conservation. Pp. 41-81 in: Clough, B.F. (ed.), The economic and environmental values of mangrove forests and their present state of conservation in South-East Asia/Pacific region. Mangrove Ecosystems Technical Reports, No. 1, ITTO/ISME/JIAM Project PD71/89, Rev. 1 (F). Nishihara, Japan: International Society for Mangrove Ecosystems (ISME), International Tropical Timber Organization (ITTO), Japan International Association for Mangroves (JIAM).

Cortés-B., R., Delprete, R.P.G. \& Motley, T. 2009. Phylogenetic placement of the tribe Retiniphylleae among the subfamily Ixoroideae (Rubiaceae). Ann. Missouri Bot. Gard. 96: 61-67.

Davis, A.P., Govaerts, R. Bridson, D.M., Rushsam, M. Moat, J. \& Brummitt, N.A. 2009. A global assessment of distribution, diversity, endemism, and taxonomic effort in the Rubiaceae. Ann. Missouri Bot. Gard. 96: 68-78.

Delprete, R.P.G. 1998. Notes on calycophyllous Rubiaceae. Part III. Systematic position of the monotypic Mexican genus Cosmocalyx and notes on the calycophyll development. Brittonia 50: 309-317.

Delprete, R.P.G. \& Cortes-B., R. 2004. A phylogenetic study of the tribe Sipaneeae (Rubiaceae, Ixoroideae), using $\operatorname{trn} L-F$ and ITS sequence data. Taxon 53: 347-356.

DENR. 1996. The Philippine Environmental Quality Report, 19901995. Quezon: Environmental Management Bureau, Department of Environment and Natural Resources.

Drummond, A.J., Ho, S.Y., Rawlence, W.N. \& Rambaut, A. 2007. A rough guide to BEAST 1.4. http://molecularevolution.org/molevol files/beast/BEAST14_MANUAL-7-6-07.pdf. 
Gelman, A. \& Rubin, D. 1992. Inference from iterative simulation using multiple sequences. Statist. Sci. 7: 457-511.

Gignoux, J., Clobert, J. \& Menaut, J.C. 1997. Alternative fire resistance strategies in savanna trees. Oecologia 110: 576-583.

Hall, T.A. 1999. BioEdit: A user-friendly biological sequence alignment editor and analysis program for Windows 95/98/NT. Nucl. Acids Symp. Sér. 41: 95-98.

Hemsley, W.B. 1916. Flora of Seychelles and Aldabra. J. Bot. 54[Suppl. 2]: $1-24$.

Hettiarachchi, P.L. \& Jayaratne, R.K. 2006. Factors limiting seed germination in Scyphiphora hydrophyllacea Gaertn f. and Pemphis acidula J R \& Forst [sic]. http://forestry2002.blogspot .com/2006/09/factors-limiting-seed-germination-in.html.

Hooker, J.D. 1873. Ordo LXXXIV. Rubiaceae. Pp. 7-151 in: Bentham, G. \& Hooker, J.D. (eds.), Genera plantarum, vol. 2, part 1. London: Reeve; Williams \& Norgate.

Huelsenbeck, J.P. \& Ronquist, F. 2001. MRBAYES: Bayesian inference of phylogeny. Bioinformatics 17: 754-755.

IUCN. 2001. IUCN Red List Categories and Criteria, version 3.1. IUCN Cambridge: Species Survival Commission.

IUCN. 2010. IUCN Red List of Threatened Species, version 2010.4. www.iucnredlist.org (accessed 4 Feb. 2011).

Jomo, K.S., Chang, Y.T. \& Khoo, K.J. 2004. Deforesting Malaysia: The political economy and social ecology of agricultural expansion and commercial logging. London: Zed Books.

Khan, S., Razafimandimbison, S.G., Bremer, B. \& Liede-Schumann, S. 2008. Sabiceeae and Virectarieae (Rubiaceae, Ixoroideae): One or two tribes? - New tribal and generic circumscriptions of Sabiceeae and biogeography of Sabicea s.1. Taxon 57: 7-23.

Kainulainen, K., Mouly, A., Khodabandeh, A. \& Bremer, B. 2009. Molecular phylogenetic analysis of the tribe Alberteae (Rubiaceae), with description of a new genus Razafimandimbisonia. Taxon 58: 757-768.

Kathirithamby-Wells, J. 2005. Nature and nation: Forests and development in Peninsular Malaysia. Singapore: NIAS Press.

Kishokumar, J. 2008. Integrated management plan of the South-East Pahang Peat Swamp Forest. PSF Technical Series, No. 9. UNDP/ GEF Peat Swamp Forest Project, Pahang Forestry Dept., Malaysia.

Korthals, P.W. 1851. Overzigt der Rubiaceën van de NederlandschOostindische Kolonien. Ned. Kruidk. Arch. 2: 196-198.

Lantz, H. \& Bremer, B. 2004. Phylogeny inferred from morphology and DNA data: Characterizing well-supported groups in Vanguerieae (Rubiaceae). Bot. J. Linn. Soc. 146: 257-283.

Malcomber, S.T. \& Davis, A.P. 2005. Six new species of Gaertnera (Rubiaceae) from Madagascar and phylogenetic analyses that support Hymenocnemis as a synonym of Gaertnera. Monogr. Syst. Bot. Missouri Bot. Gard. 104: 371-398.

Manns, U. \& Bremer, B. 2010. Towards a better understanding of intertribal relationships and stable tribal delimitations within Cinchonoideae s.s. (Rubiaceae). Molec. Phylog. Evol. 56: 21-39.

Mouly, A., Razafimandimbison, S.G., Achille, F., Haevermans, T. \& Bremer, B. 2007. Phylogenetic placement of Rhopalobrachium fragrans (Rubiaceae): Evidence from molecular (rps16 and trnT-F) and morphological data. Syst. Bot. 32: 872-882.

Mouly, A., Razafimandimbison, S.G., Florence, J., Jérémie, J. \& Bremer, B.2009. Paraphyly of Ixora and new tribal delimitation of Ixoreae (Rubiaceae): Inference from combined chloroplast (rpsl6, rbcL, and trnT-F) sequence data. Ann. Missouri Bot. Gard. 96: 146-160.

Novotny, V., Basset, Y., Miller, S.E., Weiblen, G.D., Bremer, B., Cizek, L. \& Drozd, P. 2002. Low host specificity of herbivorous insects in a tropical forest. Nature 416: 841-844.

Nylander, J.A.A., Wilgenbusch, J.C., Warren, D.L. \& Swofford, D.L. 2008. AWTY (Are We There Yet?): A system for graphical exploration of MCMC convergence in Bayesian phylogenetics. Bioinformatics 24: 581-583.

Oxelman, B., Backlund, M. \& Bremer, B. 1999. Relationships of the Buddlejaceae s.l. investigated using parsimony jackknife and branch support analysis of chloroplast $n d h F$ and $r b c L$ sequence data. Syst. Bot. 24: 164-182.

Primavera, J. 2000. Development and conservation of Philippine mangroves: Institutional issues. Ecol. Econ. 35: 91-106.

Puff, C., Chayamarit, C. \& Chamchumroon, V. 2007. Rubiaceae of Thailand: A pictorial guide to indigenous and cultivated genera. Bangkok: The Forest Herbarium, Department of National Parks, Wildlife and Conservation.

Puff, C. \& Igersheim, A. 1994. Intra-ovarian trichomes in Jackiopsis ornata (Wallich) Risdale (Rubiaceae-Jackieae). Bot. J. Linn. Soc. 115: 29-33.

Rambaut, A. \& Drummond, A.J. 2007. Tracer, version 1.4. http:// beast.bio.ed.ac.uk/Tracer.

Rana, T.S. \& Ranade, S.A. 2009. The enigma of monotypic taxa and their taxonomic implications. Curr. Sci. 96: 219-229.

Ranarivelo-Randriamboavonjy, T., Robbrecht, E., Rabakonandrianina, E. \& De Block, P. 2007. Revision of the Malagasy species of the genus Tricalysia (Rubiaceae). Bot. J. Linn. Soc. 155: 83-126.

Razafimandimbison, S.G. \& Bremer, B. 2001 [publ. 2002]. Tribal delimitation of Naucleeae (Cinchonoideae, Rubiaceae) inference from molecular and morphological data. Syst. Geogr. Pl. 71: 515-538.

Razafimandimbison, S.G. \& Bremer, B. 2002. Phylogeny and classification of Naucleeae s. 1. (Rubiaceae) inferred from molecular (ITS, $r b c L$, and trnT-F) and morphological data. Amer. J. Bot. 89: 1027-1041.

Razafimandimbison, S.G., Lantz, H., Mouly, A. \& Bremer, B. 2009. Evolutionary trends, major lineages, new generic limits in the dioecious group of the tribe Vanguerieae (Rubiaceae) insights into the evolution of functional dioecy. Ann. Missouri Bot. Gard. 96: $161-181$.

Razafimandimbison, S.G., Rydin, C. \& Bremer, B. 2008. Evolution and trends in the Psychotrieae alliance (Rubiaceae): A rarely reported evolutionary change of many-seeded carpels from oneseeded carpels. Molec. Phylog. Evol. 48: 207-223.

Ridsdale, C. 1979. Jackiopsis, a new name for Jackia Wall. (Rubiaceae - Jackieae). Blumea 25: 295-296.

Robbrecht, E. 1988. Tropical woody Rubiaceae. Opera Bot. Belg. 1: $1-271$.

Robbrecht, E. \& Manen, J-F. 2006. The major evolutionary lineages of the coffee family (Rubiaceae, angiosperms). Combined analysis (nDNA and cpDNA) to infer the position of Coptosapelta and Luculia, and supertree construction based on rbcL, rps16, trnL-F and atpB-rbcL data. Syst. Geogr. Pl. 76: 85-146.

Ronquist, F. \& Huelsenbeck, J.P. 2003. MRBAYES 3: Bayesian phylogenetic inference under mixed models. Bioinformatics 19: 1572-1574.

Rova, J.H.E., Delprete, R.P.G., Andersson, L. \& Albert, V. 2002. A trnL-F cpDNA sequence study of the Condamineeae-Rondeletieae-Sipaneeae complex with implications on the phylogeny of the Rubiaceae. Amer. J. Bot. 89: 145-159.

Rova, J.H.E., Delprete, R.P.G. \& Bremer, B. 2009. The Rondeletia complex: An attempt to use ITS, rps16, and trnL-F sequence data to delimit Guettardeae, Rondeletieae, and sections within Rondeletia. Ann. Missouri Bot. Gard. 96: 182-193.

Roxburgh, W. 1824. Flora Indica. Calcutta: Mission Press.

Rydin, C., Kainulainen, K., Razafimandimbison, S.G., Smedmark, J.E.E. \& Bremer, B. 2009. Deep divergences in the coffee family and systematic position of Acranthera. Pl. Syst. Evol. 278: 101-123.

Rydin, C., Razafimandimbison, S.G. \& Bremer, B. 2008. Rare and enigmatic genera (Dunnia, Schizocolea, and Colletoecema), sisters to species-rich clades: Phylogeny and aspects of conservation biology in the coffee family. Molec. Phylog. Evol. 48: 74-83.

Samson, N., Bausher, M.G., Lee, S.-B., Jansen, R.K. \& Daniell, H. 2007. The complete nucleotide sequence of the coffee (Coffea arabica L.) chloroplast genome: Organization and implications for biotechnology and phylogenetic relationships among angiosperms. Pl. Biotechnol. J. 5: 339-353. 
Sasekumar, A. \& Then, A.Y.H. 2005. Vegetation, forestry and conservation of Selangor mangrove forests. Pp. 57-65 in: Sasekumar, A. \& Chong, V.C. (eds.), Ecology of Klang Strait. Kuala Lumpur: University of Malaysia.

Schumann, K. 1891. Rubiaceae. Pp. 1-156 in: Engler, A. \& Prantl, K. (eds.), Die natürlichen Pflanzenfamilien, vol. 4, 4: 1. Leipzig: Engelmann.

Smith, W.W. 1917. Diagnoses specierum novarum in herbario Horti Regii Botanici Edinburgensis cognitarum (species asiaticae). CCLI-CCCL. Notes Roy. Bot. Gard. Edinburgh 10: 1-78.

Sosef, M.S., Prawirohatmodjo, M.S. \& Hong, L.T. 1998. Plant resources of South-East Asia, vol. 5 no. 3, Timber trees: Lesserknown timbers. Leiden: Backhuys.

Stoffelen, P., Robbrecht, E. \& Smets, E. 1996. A revision of Corynanthe and Pausinystalia (African Rubiaceae-Coptosapelteae). Bot. J. Linn. Soc. 120: 287-326.

Swofford, D.L. 2002. PAUP*: Phylogenetic analysis using parsimony (*and other methods). Sunderland, Massachusetts: Sinauer.

Thompson, J.D., Higgins, D.G. \& Gibson, T.J. 1994. CLUSTAL W: Improving the sensitivity of progressive multiple sequence alignment through sequence weighting, positions-specific gap penalties and weight matrix choice. Nucl. Acids Res. 22: 4673-4680.

Tirvengadum, D.D. 1984. Glionnetia, un nouveau genre de Rubiacées (Rondélétiées) des Seychelles. Bull. Mus. Natl. Hist. Nat., B, Adansonia 6: 197-205.

Tomlinson, P.H. 1986. The botany of mangroves. Cambridge: Cambridge University Press.

Tosh, J., Davis, A.P., Dessein, S., De Block, P., Huysmans, S., Fay, M.F., Smets, E. \& Robbrecht, E. 2009. Phylogeny of Tricalysia (Rubiaceae) and its relationships with allied genera based on based plastid DNA data: Resurrection of the genus Empogona. Ann. Missouri Bot. Gard. 96: 194-213.

UNEP World Conservation Monitoring Centre. 2008. Strategies for the sustainable use and management of timber species subject to international trade; South East Asia. Cambridge, U.K.: UNEPWCMC.

Villaluz, D.K. 1953. Fish farming in the Philippines. Manila: Bookman.

Xiao, L.-Q. \& Zhu, H. 2007. Paraphyly and phylogenetic relationships in Lasianthus (Rubiaceae) inferred from chloroplast rps16 data. Bot. Stud. 48: 225-232.

Appendix. Species sampled for the study.

Species, accession nos. [ $n d h F, r b c L$, rps 16, trnT-F; an n-dash (-) denotes missing data; superscripts 1-27 refer to literature or GenBank sources, superscripts 28-37 refer to voucher specimens and herbarium acronyms, both given at the end of the Appendix].

Acranthera frutescens Valeton, -, AM1171989, -,-; Acranthera grandiflora Bedd., -, AM1171999, -, -; Alstonia scholaris (L.) R. Br., -, X91760²8,-,-; Amphidasya ambigua Standl.) Standl., -, Y1184420,-, -; Arcytophyllum aristatum Standl., -, AJ28859529, -, -; Anthocleista Afzel. ex R. Br., -, L1438930,-,-; Anthospermum herbaceum L.f., -, X83623 ${ }^{10},-,-$; Airosperma vanuense S.P. Darwin, AM949845 ${ }^{1},-$, FM204700 ${ }^{1}$, FM207108 ${ }^{1}$; Alberta magna E. Mey., AJ236282 EU8174117 FM204701 ${ }^{1}$ AJ6201184; Aleisanthia rupestris (Ridl.) Ridl., -, -, AF242902 ${ }^{6}$, AF1526605; Aleisanthiopsis distantiflora (Merr.) Tange, HM16435028, EU8174117 , EU8174347 , EU8174537; Aidia micrantha (K. Schum.) Bullock ex F. White, -, Z68844 ${ }^{15},-,-;$ Argostemma hookeri King, -, Z68788 ${ }^{31},-,-;$ Augusta

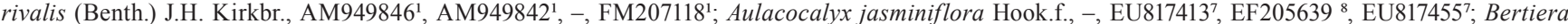

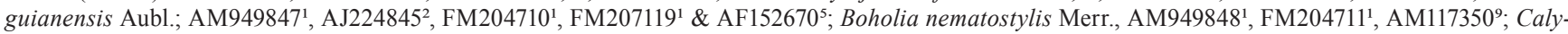
cophyllum candidissimum (Vahl) DC., AJ236285², X83627 ${ }^{10}$, FM204712¹, AJ847398 ${ }^{11}$; Canthium tetraphyllum (Schweinf. ex Hiern) Robyns, AM949849 ${ }^{1}$ X83649 ${ }^{10}$, FM204713', FM207120'; Carphalea glaucescens (Hiern) Verdc., -, Z68789 ${ }^{31},-,-$; Catesbaea spinosa L., -, X83628 ${ }^{10},-,-$; Chioccoca alba (L.)

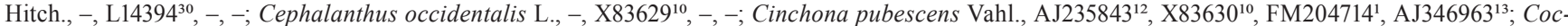
cocypselum hirsutum Bartl. ex DC., -, X87145 ${ }^{10},-,-$; Coffea arabica L., EF044213 ${ }^{14}$, EF044213 ${ }^{14}$, EF044213 ${ }^{14}$, EF044213 ${ }^{14}$; Colletoecema dewevrei (De Wild.) E.M.A. Petit, -, EU14545723,-,-; Condaminea corymbosa (Ruiz \& Pav.) DC., -, Y187133,,$--;$ Coptosapelta diffusa Steenis, - , EU145452 ${ }^{23},-,-;$ Coptosapelta flavescens Korth.,-, Y18714³,-,-; Coptosapelta montana Korth. ex Valeton, -, EU14545123, -, -; Coussarea macrophylla (Mart.) Müll. Arg., -, Y11847³, -,

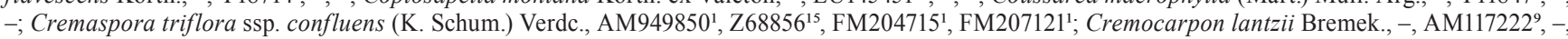

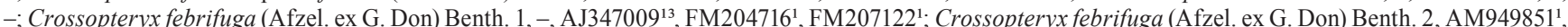
AM117223', FM204717', FM207123'; Cruckshancksia hymenodon Hook. \& Arn., -, AJ28859929, -, -; Cubanola domingensis (Britton) Aiello, AM1173459,

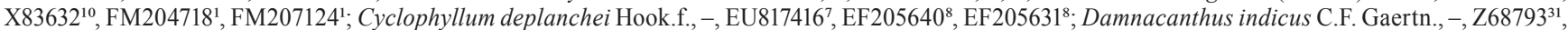
-,-; Danais xanthorrhoea (K. Schum.) Bremek.,-, Z68794¹, -,-; Declieuxia cordigera Mart. \& Zucc. ex Scult. \& Schult.f., -, AM1172249, -,-; Dibrachiono-

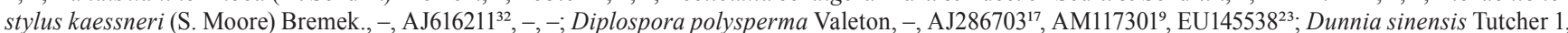
-, EU145467²3,-,-; Dydimaea alsinoides (Cham. \& Schtdl.) Standl.,-, Z68795¹, -, -; Emmenopterys henryi Oliv., AJ236294 ${ }^{3}$, Y18715³, FM204719', FM207125'; Ernodea littoralis Sw., -, AJ28860129, -, -; Faramea multiflora A. Rich., -, Z68796 ${ }^{31},-,-;$ Ferdinandusa speciosa Pohl., -, AM1172269 ,-, -; Feretia aeruginescens Stapf, -, Z6885731, -, -; Fernelia buxifolia Lam., -, AJ28670417, -, -; Galium album Mill., -, X8109010, -, -; Gardenia hansemannii K. Schum.,

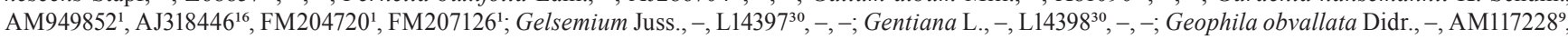
-, -; Glionnetia sericea (Baker) Tirveng. 1, HM536216 ${ }^{29}$. HM536222 ${ }^{29}$. HM536228 ${ }^{29}$, HM536234 ${ }^{29}$; Glionnetia sericea (Baker) Tirveng. 2, HM53621730, HM536223 $3^{30}$, HM536229 $9^{30}$, HM536235 ${ }^{30}$; Glionnetia sericea (Baker) Tirveng. 3, HM536218 ${ }^{31}$, HM536224 ${ }^{31}$, HM536230 ${ }^{31}$, HM536236 ${ }^{31}$; Greenea corymbosa (Jack) Volgt, -,-, AF2429616 , AF1526575; Greenea oblonga Craib, HM164371², -, EU8174597; EU8174397; Greenea sp. 1, -, -, EU8174387, EU8174587; Greenea sp. 2, -, EU8174187, EU8174407, EU8174607; Guettarda uruguensis Cham. \& Schltdl., -, X83638 ${ }^{10},-,-;$, Gynochthodes coriacea Blume, -, AJ28860329,-, -; Hedyotis fruticosa L., -, Z6879931, -, -; Hillia triflora (Oerst.) C.M. Taylor; -, X8364210;, -, -,; Houstonia caerutea L., -, AJ28860429, -, -; Hydnophytum

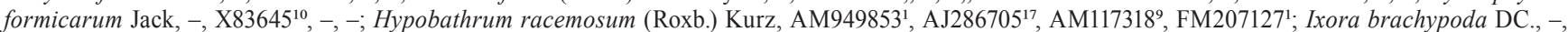
EU8174217, EU8174427, EU8174637; Ixora coccinea L., AJ236299³ ${ }^{3}$ X83646 ${ }^{10}$, EF2056418, EU8174647; Ixora guineensis Benth., -, EU8174247, EU8174437, EU8174677; Ixora hookeri (Oudem.) Bremek.; -, EU8174257', EU81744377, EU8174677; Ixora margaretae N. Hallé, -, EU8174257, EU8174447, EU8174687; Ixora moorensis (Nadeaud) Fosberg, -, EU81742077, EU8174417, EU8174627; Ixora trilocularis (Balf.f.) Mouly \& B. Bremer, -, EU8174177, EU8174377, EU8174577;

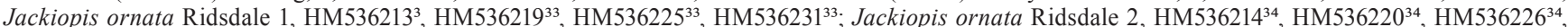
HM536232 ${ }^{34}$; Jackiopis ornata Ridsdale 3, HM536215 ${ }^{35}$, HM536221 ${ }^{35}$, HM53622735, HM536233 ${ }^{35}$; Keetia gueinzii (Sond.) Bridson, -, -, AM1173239 , AJ6201439; Kohautia caespitosa Schnizl.,-, Z6880031,-,-; Kraussia floribunda Harv., -, Z68858 31 ,-,-; Lasianthus pedunculatus (Griseb.) Urb., -, Z6880231,-,-; Lerchea

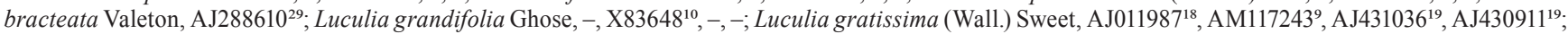
Luculia pinceana Hook., -, EU14544723, -, -; Manostachya ternifolia E.S. Martins, AJ616213 ${ }^{20}$; Margaritopsis acutifolia C. Wright, -, AM1172479, -, -; Maschalocorymbus corymbus (Blume) Bremek., -, AJ28861129,-,-; Mitchella repens L., -, Z68805 ${ }^{31},-,-;$ Mitrasacmopsis quadravalvis Jovet, -, AJ616214 ${ }^{20}$,

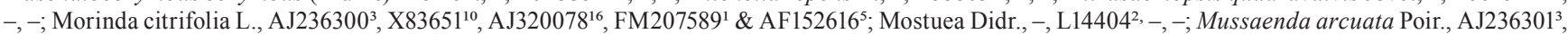
Y11854 ${ }^{20}$, FM204721 ${ }^{1}$, FM207128'; Mussaenda erythrophylla Schumach. \& Thonn., -, X83652'; Mycetia malayana (G. Don) Craib, -, Z68806 ${ }^{31},-,-;$, Nauclea

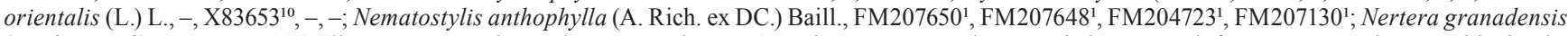
(Mutis ex L.f.) Druce, - , X83654 ${ }^{10},-,-$; Neurocalyx zeylanicus Hook., -, Z68807³, -, -; Normandia neocaledonica Hook.f., -, AM1172509, -, -; Oldenlandia corymbosa L., -, X83655 ${ }^{10},-,-$; Ophiorrhiza mungos L., -, X83656 ${ }^{10},-,-$; Oreopolus glacialis (poepp.) Ricardi, -, AJ288612 ${ }^{29},-,-$; Paederia foetida L., -, AF332373 $33,-,-;$ Palicourea crocea (Sw.) Schult, -, AM1172539, -,-; Parapentas silvatica (K. Schum.) Bremek., -, X8365710,-,-; Pauridiantha paucinervis

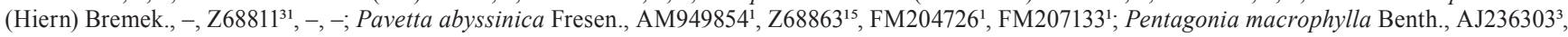


Appendix. Continued.

X83658 ${ }^{10}$, FM2047271, FM207134'; Pentas lanceolata (Forssk.) Deflers., -, Z83659¹, -, -; Pentodon pentandrus (Schumach. \& Thonn.) Vatke. Oesterr., -, X83660 ${ }^{10},-,-;$ Peponidium comorense Arènes,,,-- EF205646 ${ }^{8}$ EF205632 ${ }^{8} ;$ Posoqueria latifolia (Rudge) Roem. \& Schult., AM949855 ${ }^{1}, Z_{68850}{ }^{15}$, FM204728 ${ }^{1}$, FM207135'; Pouchetia gilletii De Wild., -, Z6885915, -, -; Praravinia suberosa (Merr.) Bremek., -, AJ28861629, -, -; Pseudomussaenda flava Verdc.,

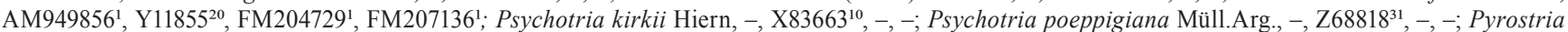
hystrix (Bremk.) Bridson, EU145418²3, AM1172629, AM1173389, AJ6201684; Razafimandimbisonia minor (Baill.) Kainul. \& B. Bremer, AM949844', EU8174107, EF205637 ${ }^{8}$, EU8174527 ; Razafimandimbisonia sambiranensis (Homolle ex Cavaco) Kainul. \& B. Bremer, -, EU8174317, EF205645 ${ }^{8}$, EU8174747; Retiniphyllum concolor (Spruce ex Benth.) Müll.Arg., -, -, EU82162924 EU82164124; Retiniphyllum maguirei Stand1., -, -, EU821632 ${ }^{24}$ EU82164624; Retiniphyllum pilosum (Spruce ex Benth.) Müll.Arg., -, AF33165421, FM2047301, FM2071371; Retiniphyllum schomburgki (Benth.) Müll.Arg., -, -, EU82163124, EU82164524 ; Rhachicallis americana (Jacq.) Hitchc., -, X83664 ${ }^{10},-$,-; Rondeletia odorata Jacq., -, Y1185720, -, -; Rubia tinctorum L., -, X83666 ${ }^{10},-,-$; Rustia thibaudioides (H. Karst.) Delprete, AJ236310³, Y18716³, FM204731', FM207138'; Sabicea aspera Aubl., -, AY53850822, -, -; Sabicea diversifolia Pers., -, EU145459²3, -, -;

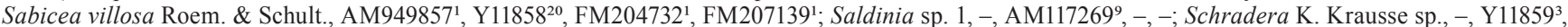
-, -; Schismatoclada sp., -, AM1172719, -, -; Schizocolea linderi (Hutch. \& Dalziel) Bremek., -, AM1172729, -, -; Scyphiphora hydrophylacea C.F. Gaertn.

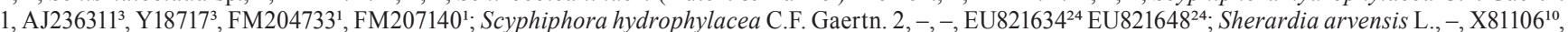

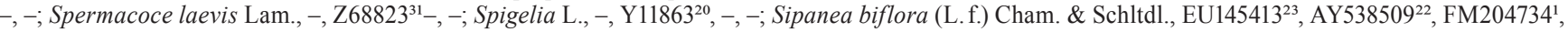
FM207141'; Sipanea hispida Benth. ex Wernham, EU145414 ${ }^{23}$, EU145458 ${ }^{23}$, EU145492 ${ }^{23}$, AY55510727; Sipanea pratensis Aubl., -, -, AF243022 ${ }^{6}$, AF1526775; Spiradiclis bifida Kutz, -, EU145465, -, -; Steenisia pleurocarpa (Airy Shaw) Bakh.f., -, AM117279², FM204735', FM207142'; Strychnos L., -, L1441028, -, -; Tamridaea capsulifera (Balf.f.) Thulin \& B. Bremer, -, Y1186020, FM2047361', FM207143'; Tennantia sennii (Chiov.) Verdc. \& Bridson, AM9498581,

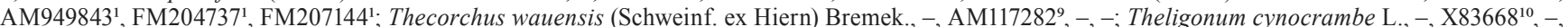

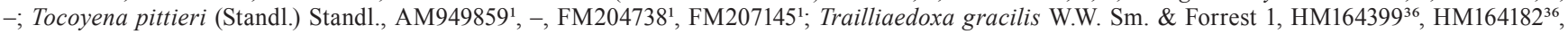

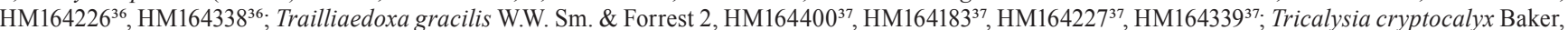
-, Z68854 ${ }^{15}$, AF00408826, AM99948725; Trichostachys aurea Hiern, -, EU145462 ${ }^{23},-,-$; Trichostachys sp., -, AJ288626 ${ }^{29}$,-,-; Urophyllum ellipticum (Wight) Thwaites, -, X83670 ${ }^{10},-$, ,-; Vangueria madagascariensis J.F. Gmel., AJ130840³, X83670 ${ }^{10}$, EU821636 ${ }^{24}$, FM207146'; Virectaria major (K. Schum.) Verdc., -, Y1186120,-, -; Xanthophytum borneense (Valeton) Axelius, -, EU145466 ${ }^{23},-,-$; Wendlandia tinctoria (Roxb.) DC., AM949860', FM207649'1 FM2047391, FM2071471.

Published sequences: 1, Kainulainen \& al. (2009); 2, Andreasen \& al. (1999); 3, Bremer \& al. (1999); 4, Lantz \& Bremer (2004); 5, Rova \& al. (2002); 6, Rova, J.H.E. (Genbank unpub.); 7, Mouly \& al. (2009); 8, Mouly \& al. (2007); 9, Bremer \& Eriksson (2009); 10, Bremer \& al. (1995); 11, Alejandro \& al. (2005); 12, Backlund \& al. (2000); 13, Razafimandimbison \& Bremer (2002); 14, Samson \& al. (2007); 15, Andreasen \& Bremer (1996); 16, Novotny \& al. (2002); 17, Andreasen \& Bremer (2000); 18, Oxelman \& al. (1999); 19, Bremer \& al. (2002); 20, Bremer \& Thulin (1998); 21, Andersson, L. (Genbank unpub.); 22, Andersson \& Antonelli (2005); 23, Rydin \& al. (2008); 24, Cortes-B. \& al. (2009); 25, Tosh \& al. (2009); 26, Andersson \& Rova (1999); 27, Delprete \& Cortes-B. (2004) .

Voucher information: 28, Tange 46977 (AAU); 29, Beaver 3 (S); 30, Beaver 17 (S); 31, Beaver 27 (S); 32, Larsen K. \& Larsen S.S. 33451 (P); 33 , Tan s.n. (Malaysia), cA047; 34, Tan s.n. (Malaysia), cA048; 35, Tan s.n. (Malaysia), cA049; 36, Yü 1348 (HUH); 37, Boufford \& al. 35041 (MO) . 